\title{
Boy Life in a Massachusetts Country Town Forty Years Ago
}

\section{G. Stanley Hall}

To cite this article: G. Stanley Hall (1906) Boy Life in a Massachusetts Country Town Forty Years Ago, The Pedagogical Seminary, 13:2, 192-207, DOI: 10.1080/08919402.1906.10532538

To link to this article: http://dx.doi.org/10.1080/08919402.1906.10532538

曲 Published online: 30 Aug 2012.

Submit your article to this journal $\widetilde{ }$

Џ Article views: 3

Q View related articles ¿ 
By G. STANLEy Hail.

Between the ages of nine and fourteen, my parents, who then lived in a distant town, very wisely permitted me to spend most of the school-less part of these five years, so critical for a boy's development, with a large family on a large farm in Ashfield of this State. Although this joyous period ended long ago, the life, modes of thought and feeling; industries, dress, etc., were very old-fashioned for that date, and were tenaciously and proudly kept so. In more recent years, as I have come to believe that nowhere does the old New England life still persist more strongly or can be studied more objectively, I have spent portions of several summers, with the aid of a small fund placed in my hands for the purpose, in collecting old farm tools, household utensils, furniture, articles of dress, and hundreds of miscellaneous old objects into a local museum, a little after the fashion of the museums of Plymouth, Salem and Deerfield. I have interviewed all the oldest inhabitants for details of customs, industries, persons, become interested in a map of the original farms, verified in part by old walls and cellar holes and apple trees, and compiled a brief history of the town. My vacation interest grew into a record partly because so many facts of the early life and thoughts of old New England are still unrecorded and are now so fast passing beyond the reach of record, with the lamented decay of these little oid towns, partly because despite certain evils this life at its best appears to me to have constituted about the best educational environment for boys at a certain stage of their development ever realized in history, combining physical, industrial, technical with civil and religious elements in wise proportions and pedagogic objectivity. Again, this mode of life is the one and the only one that represents the ideal basis of a state of citizen voters as contemplated by the framers of our institutions. Finally, it is more and more refreshing in our age, and especially in the vaaction mood, to go back to sources, to the fresh primary thoughts, feelings, beliefs, modes of life of simple, homely, genuine men. Our higher anthropology labors to start afresh from the common vulgar standpoint, as Socrates did, from what Maurice calls the Ethos, and Grote the Nomos of common people, and of a just preceding and a vanishing type of civilization, to

\footnotetext{
${ }^{1}$ Reprinted from Proc. of the Am. Autiq. Soc., I8gi, N. S. Vol 7, pp. 107-1 28.
} 
be warmed with its experience and saturated with its local color.

I have freely eked out the boyish memory of those five years with that of older persons, but everything that follows was in Ashfield within the memory of people living there a few years ago. Time allows me to present here but a small part of the entire record, to sample it here and there, and show a few obvious lessons.

I begin with winter, when men's industries were most diversified, and were largely in wood. Lumber-or timber-trees were chopped down and cut by two men working a cross-cut saw, which was always getting stuck fast, in a pinch which took the set out of it, unless the whole trunk was pried up by skids. Sometimes the fallen trees were cut into logs, snaked together, and piled with the aid of cant-hooks, to be drawn across the frozen pond to the saw-mill for some contemplated building, or, if of spruce, of straight grain and few knots, or of good rift, they were cut in bolts, or cross-sections of fifteen inches long, which was the legal length for shingles. These were taken home in a pung, split with beetle and wedge, and then with a frow, and finished off with a drawshave, on a shavinghorse, itself home-made. These rive shingles were thought far more durable than those cut into shape by the buzz-saw which does not follow the grain. To be of prime quality these must be made of heart and not sap wood, nor of second growth trees. The shavings were in wide demand for kindling fires. Axehelves, too, were sawn, split, hewn, whittled, and scraped into shape with bits of broken glass, and the forms peculiar to each local maker were as characteristic as the style of painter or poet, and were widely known, compared and criticised. Butter-paddles were commonly made of red cherry, while sugar lap paddles were made by merely barking whistle wood or bass, and whittling down one end for a handle. Mauls and beetles were made of ash-knots, ox-bows of walnut, held in shape till seasoned by withes of yellow birch, from which also birch brushes and brooms were manufactured on winter evenings by stripping down seams of wood in the green. There were salt mortars and pig-troughs made from solid logs, with tools hardly more effective than those the Indian uses for his dug-out. Flails for next year's threshing; cheese-hoops and cheese-ladders; breadtroughs, and yokes for hogs and sheep, and pokes for jumping cattle, horses and unruly geese, and stanchions for cows. Some took this season for cutting next summer's bean and hop poles, pea bush, cart and sled stakes, with an eye always out for a straight clean whip stock or fish pole. Repairs were made during this season, and a new cat-hole beside the door, with a laterally working drop-lid, which the cat operated with ease, was 
made one winter. New sled neaps, and fingers for the grain cradle, handles for shovels and dung-forks, pitchforks, spades, spuds, hoes, and a little earlier, for rakes; scythes and brooms were home-made, and machines and men of special trades were so far uncalled for. Nearly all these forms of domestic woodwork I saw, and even helped in as a boy of ten might, or imitated them in play in those thrice-happy days; while in elder pop-guns, with a ringing report, that were almost dangerous indoors; hemlock bows and arrows, or cross bows, with arrowheads run on with melted lead (for which every scrap of lead pipe or antique pewter dish was in great demand) often fatal for very small game; box and figure 4 traps for rats and squirrels; windmills; weather vanes in the form of fish, roosters or even ships; an actual saw-mill that went in the brook, and cut planks with marino and black and white Carter potatoes for logs; and mauy whittled tools, toys and ornamental forms and puppets; -in all these and many more, I even became in a short time, a fairly average expert as compared with other boys, at least so I then thought. How much all this has served me since, in the laboratory, in daily life, and even in the study, it would be hard to estimate.

The home industry in woolen is a good instance of one which survives in occasional families to this day. Sheep, as I remember, could thrive on the poorest hay, or orts, the leavings of the neat cattle. In summer they could eat brakes and polipods, if not even hardhack and tansy, and would browse down berry briers and underbrush, while their teeth cut the grass so close that cows could hardly survive in the same pasture with them. The spring lambs were raised in the shed by hand, sometimes as cossets by the children, who often derived their first savings therefrom. Sheep washing day was a gala day when, if at no other time, liquor was used against exposure; and shearing, which came a week or two later, was hardly less interesting. A good shearer, who had done his twenty-five head a day, commanded good wages, seventy-five cents or a dollar a day; while the boys must pull the dead sheep, even though they were only found after being some weeks defunct. Fleeces for home use were looked over, all burrs and shives picked out, and they were then oiled with poor lard. "Bees" to do this were often held. Carding early became specialized, and carders were in every town, but the implements were in each family, some members of which could not only card, but could even use the fine, long-toothed worsted combs in an emergency. The rolls were spun at home, novices doing the woof or filling, and the older girls the warp, which must be of better quality. It was taken from the spindle sometimes on a niddynoddy held in the hand, at two rounds per yard, but more com- 
monly on a reel, in rounds of two yards each. Every forty rounds was signalized on a reel by the snap of a wooden spring or the fall of a hammer, and constituted a knot, four, five, seven, or ten of which (in different families and for different purposes) constituting a skein, and twenty knots making a run. Four seven-knotted skeins of filling, or six of warp was a day's work, though now, I am told, few young women can accomplish so much without excessive fatigue. The yarn, doubled if for stockings, after being washed clean of grease, next went to the great dye-tub in the chimney corner. Butternut bark for every-day suits, indigo for Sunday suits, and madder for shirting was the rule. There were also fancy dyes and fancy dyeing, braiding, binding tightly or twisting in a white thread to get the favorite hit or miss, or pepper-and-salt effect, a now almost incredible ingenuity in making up figures and fancy color effects for loom patterns in girls' dresses. Next the filling was quilled and the warp spooled, the former ready for the shuttle, and the latter for the warping bars (both of these latter being often home-made), to which it goes from the scarn or spool-frame. In warping, the leese must be taken with care, for if the order of the threads is lost they cannot be properly thumbed through the harnesses and hooked through the reed, and are good for nothing but to make into clothes lines and the piece is lost. A raddle also acts in keeping the warp disentangled and of proper width before the lathe and tenters can hold it. Sometimes blue and white shirt-formed frock cloth was woven, sometimes kerseys and plaid dress patterns of many colors, or woolen sheets, and even woolen pillow-cases, which were as warm and heavy, although coarser, than those the olfactorial zoölogist Jäeger advises, and sells to his followers. The complication of harnesses and treadles required to weave some of the more complicated carpet, and especially coverlid patterns, evinced great ingenuity and long study, and is probably now, although the combinations were carefully written down, iu most communities a forever lost art. On coming from the loom the cloth was wet for shrinkage, and the nap picked up with cards of home grown teasels and sheared smooth on one side, although in those day's this process had already gone to the local fuller. Coarse yarn was also spun from tag-locks, which was, of course, home carded. Knitting was easy, pretty, visiting work. Girls earned from two to three York shillings a pair for men's stockings, paid in trade from the store, which put out such work if desired. Shag mittens were knit from thrumbs or the left-over ends of warp. Nubias and sontags were knit with large wooden needles, and men's gloves, tidies, and clock stockings with ornamental open work in the sides were knit with one hook, and the tape loom held between the knees was kept going evenings. 
Domestic flax industry still lingers in a few families. The seed was sown broadcast and grew till the bolls were ripe, when it was pulled and laid in rows by the boys and whipped, in a few days, to get the seed for meal. After lying out of doors for some weeks till the shives were rotten, it was put through the process of breaking on the ponderous flax-break. It was then swingled, hatchelled, and finally hanked. It was then wound on the distaff made of a young spruce top, and drawn out for spinning. Grasshopper years, when the fibre was short, this was hard, and though ticking, meal bags and scratchy tow shirts could be made, finer linen products were impossible. After weaving it must be bleached in a good quality of air.

However it was with adults, child life was full of amusements. Children were numerous in every neighborhood, and though they were each required to be useful, they were in early years left much to themselves and were at home in every house, barn, or shed, within a mile or more. There was, of course, coasting, skating, swimming, gool, fox and hounds, and snowballing, with choosing of sides, lasting for a whole school term, with elaborate forts; cart wheel and men o' morn's in the snow; collar and elbow, or square hold wrestling, with its many different trips, locks and play-ups-side and back hold being unscientific; round ball; two and four old cat, with soft yarn balls thrown at the runner. The older girl-boys spent the hour's nooning in the schoolhouse and either paired off for small games or talks, or played "Here we stand all round this ring," "Needle's eye," "Kitty corners," or "Who's got the button." As in the age of Shakespeare the queen's maids of honor played tag, so here all children, and even adults often played child's games with gusto. In the family, as they gathered about the stove, or sometimes about the grand old fireplace in the back kitchen, with its back-log, crane, pot hooks and trammels, there were stories of the old fort, of bears, wild cats, Indians and Bloody Brook, and other probably unprinted tales perhaps many generations old. There were some who could sing old English ballads that had come down by tradition, and which had never been in print in America, and more who could sing a comic song or pathetic negro melody. Lord Lovel, Irving, Bunyan, The Youth's Companion and many Sunday-school books were read aloud. A pair of skates was earned by a boy friend one winter by reading the entire Bible through, and another bought an accordion with money earned by braiding the plain sides of palm-leaf hats where no splicing was needed, for the women at a cent per side. All families allowed the game of fox and geese, a few permitted checkers, and one, backgammon, which was generally thought to be almost gambling; dominoes were barely tolerated, but riddles, rebuses and charades were in high 
favor by old and young, and were published in all the local weekly papers. It was here that I learned that card playing, which I had often seen before but did not much understand nor care for, was very wrong, and a boy friend was taught old sledge, and euchre, up over the horse sheds on Sundays between services, by an older son of the officiating minister. There were hull-gull; cats-cradle with two series of changes; string and knot puzzles; odd and even, and most of the games, and many more than those in Mr. Newel's charming, and largely original, book entitled, "The Plays and Games of American Children," connecting many of them conclusively with the sports and pastimes of the English people in the merry olden time of Brandt. One maiden lady, whom we all loved, could spell "The Abominable Bumble Bee with his Head Cut Off," in an inverse House-that-Jack-built fashion, with a most sidesplitting effect. There was the charming story of the big, little and middle sized bear, and I recall the thrill when at the turn of the story, "the dog began to worry the cat, the cat began to kill the rat, the rat began to eat the corn," etc. There were beech-and chestnutting parties; raisings; and days set apart for all the men in the district being warned out by the surveyor to gather and work on the roads with teams. Work was easy, as it was for the town, and stories were plenty. There were huskings, with cider and pumpkin pie, and games on the barn floor, when it was cleared of corn; paring bees, with bobbing, swinging a whole paring thrice around the head, thence to fall on the floor in the form of the fancied initial of some person of the other sex; and counting seeds to the familiar doggerel-one I love, two I love, three I love I say, four I love with all my heart, and five I cast away, etc. Here the apples were quartered and strung, and hung in festoons to dry all over the kitchen. There were quilting bees for girls about to marry, where the men came in the evening and partook of the new species of rice pop-corn, served in two large milk pans, with, perhaps, the most delicious home-made spruce and wintergreen beer. Spelling schools in which the parents took part, and where the champion spellers of rural districts, after exhausting several spelling books, agreed to spell each other down on an abridged Worcester's dictionary. 'There were weekly evening singing schools in winter, and several of us taught ourselves or each other to play the accordion, and fiddle by rote, to dance single and double shuffle on a board, and the steps of waltz, polka and schottische. Even square dances were attempted to our own music, if we could get a caller-off. This latter was here a stolen sweet, as was the furtive reading of the thrilling tales of the New York Ledger, especially those of Sylvanus $\mathrm{Cobb}$, sets of which were smuggled around among the boys and 
read after retiring, or in sheep shed, hay mow, or attic, on rainy days. I must not forget the rage for trapping and hunting, by which we learned much of the habits of crows, hawks, muskrats, woodchucks, squirrels, partridges and even foxes, and which made us acquainted with wide areas of territory. In a regular squirrel hunt organized by choosing sides, and a dinner to the victors paid for by the vanquished party, as determined by counting tails, boys of my age were not old enough to participate. We made collections, however, for whole seasons, of heads, legs, wings, and tails, as well as of woods, leaves, flowers, stones, bugs, butterflies, etc.

The dull days in haying time brought another sort of education. The men of the vicinity strolled together in a shed, and sitting on tool bench, grindstone, manger, wagons, chopping blocks, and hog spouts, discussed crop prices, ditching, walling, salting cattle, finding springs with witch hazel, taxes, the preaching, the next selectmen, fence-viewer, constable, and, I suppose a little earlier, wardens, leather sealers, deer reeves, surveyors of shingles and clapboards and of wheat, field drivers, tithing men, clerk of the market, and pound-keepers, as well as the good brooks and ponds for trouting, or snaring pickerel with brass wire loops and a white-birch-bark light at night, and every sort of gossip. The old uncles who came to be the heroes of current stories, and who were, in a sense, ideal men, were shrewd and sharp, of exceeding few words, but these oracular, of most unpromising exteriors and mode of speech, with quaint and eccentric ways which made their quintessential wisdom very surprising by the contrast; while in weather signs and in drugs the old Indian was sometimes the sage. At the opposite extreme was the unseasoned fellow who can be fooled and not get the best of it if he was "run" or played some practical joke. Absurb exaggerations told with a serious air, to test the hearer's knowledge or credulity, were the chief ingredients of this lowery-day wit. Thus the ass's head was not unfrequently clapped on some poor rich fellow, green from the city, or some larger town, suspected of the unpardonable sin of being "stuck up."

In this air a good "nag" has great viability. As a boy here, $e . g .$, I often played hunt, snapping a disabled old flint-lock musket at every live thing in field and forest, for which an adult neighbor used to "run" me unmercifully before the whole shed. Years after, when I was at home on a college outing, he had not forgotten it, and for perhaps a dozen summers since $I$ have met it. On a recent evening, when walking with a dig. nified city friend, he met me with the same old grind, "Hello, huntin' much this summer with Philander's old gun?"' as he slapped bis thighs and laughed till the hills rang, and, though 
I did not hear him, I am no less certain that he said to the neighbor with him, when they had ridden well by, that I was always a pretty middlin' good sort of a fellow after all, and was n't stuck up. The joke will no doubt keep fresh another quarter of a century if my friend lives, and there are many more of the same kind. Another grind at my expense illustrates the inventive cleverness of this old Yankee type. As one of the speakers at an annual dinner in honor of the old town Academy, I had been several times introduced as a specimen of the former students of the Academy. One night, at the crowded post-office, this shrewd old farmer told, in my presence and for my benefit, the story of old Joe W., who went on the road as a drummer for the old tannery. He said Joe had just experienced religion, and was just then so all-fired honest that he selected, as the samples he was to sell from, pieces of sole leather a trifle below the average quality, instead of above, as an honest drummer should do. He was afraid to hope that Professor N., who presided at the dinner, had experienced religion, but leastways he was so all-fired honest that he leaned over backwards worse than old Joe in calling me out as a sample Academy boy, for although I was middling smart there was not a boy of them who was n't a plaguey sight smarter than I was. Another of his stories was of Stephen and Ann. They were courting, and she had sat in his lap in the kitchen one Sunday evening for some hours, when she suddenly asked if he was not tired. He gallantly replied, "Not a mite, Ann, keep right on settin'. I was awful tired an hour ago, but now I am numb." That is the way he said it was probably with my hearers and pupils.

Then there was the story of old Deacon S., who sold homemade cider brandy or twisted cider, at the rate of twenty-five cents per gallon, but who always used to get his big thumb into the quart measure, which had lost its handle, displacing its cubic contents of brandy. There was another tale of Captain A., who being cheated in a horse trade by Mr. B., called all his sons and grandsons together solemnly, as if for family prayers, told them the circumstances, and enjoined them to cheat B. back to the amount of six dollars, and if they did not live to do it to teach their children and grandchildren to cheat his descendants to the end of time; but a few months later. after another trade with B., the captain convened his family again to say that the score had been paid with interest, and to release them from the covenant. There was the story of Uncle G., who began his courtship by "creepin' in, all unbeknown," behind his best girl, stealing up close behind her as she was washing dishes, hat on and chair in hand, with the salute, "Well Sal, feel kind'er sparky to-night?" to which she coquet- 
tishly but encouragingly replied, "Well, I reckon p'raps a leetle more sorter than sorter not;" and how at last, the minister being away, they rode together on one horse twenty miles alone, and were married. There was the legend of old Squire V., who used to be a great favorite with the girls. Driving up to the town clerk's door one day he told him to have him "published" the next Sunday with Miss B. and drove off. Soon he returned and desired the name changed to Miss C., and finally, after several changes and some minutes of profound deliberation, settled on Miss $\mathrm{H}$., whom he married. There was the tale of the turning of the Deerfield River by the two great but mystic ancestors of one family in town. It once flowed down the gap. in Mr. P.'s pasture, through the pond and over the plain of the village, and was stipulated as the northern boundary of the possessions of these pioneers. They were ambitious, and had noticed that new settlers and their depredations followed rivers, so they hired hundreds of Indians to dig with sharpened sticks, day and night, one entire summer, till the stream at length washed over down a more northerly valley so suddenly as to sweep away the dusky maiden beloved by one of the pioneers; with many other romantic incidents. There was tha story of the old horse jockey G., who in his travels found a negro of great strength but so simple as to agree to work for him a hundred years, on the expiration of which time the old jockey was to give him all the property and serve him a century; and who cured him of the inveterate habit of sucking eggs by showing him a dozen, apparently freshly laid, in his bed one morning just after he had risen, and frightening him out of the practice by convincing him that he had laid the eggs while he slept. There was the story of the old cat ground up in the mill with dreadful caterwaulings, and of the two bushels of good rye required to grind the millstones clean again. Another, was of the case, famous in history, of the non-conforming Baptist deacon who would not pay his town tax to support the Congregational preaching, and whose apple trees were dug up by the constable and sold for payment; of the deacon's going to Boston to the General Court, and of his return with a barrel of cider brandy drawn on two poles strapped together, one end of each in the holdbacks and the other end dragging on the ground. There were stories of a noted lady pioneer in the cause of female education, who solicited domestic utensils and produce of every kind for a young ladies' seminary, following the men into stable and around hay mow in her quest; of old Heeber, suspected of witchcraft, who lived apart and was buried outside the cemetery; of old Sloper, who had no friends, and vanished so mysteriously that gradually a detailed story of his murder by a 
prominent, but not beloved, citizen was evolved; of the old church, stone cold in winter, with two services and sermons from ten to four, and in summer with the rocks black at nooning with people, mostly members in close communion, eating their Sunday dinner, and picking caraway or meetin'-seed; of the waste of timber, or the greed of individuals in shacking hogs on the then extensive undivided land or common, and even of the secular variations of the compass to account for the disparity between the old surveys of boundary lines and new ones.

Evenings in the kitchen were spent in light work and gossip unremitting. Candles, in olden times before cotton, it is said, were made by loosely spinning tow-wicking. Candle rods were then whittled out or cut from cat-tails, on which wicking for a dozen candles was put, and they were hung over the back of an old, high, straight-backed chair tipped down, and dipped every few minutes in beef, or better, mutton tallow melted in the tin boiler. Of course candles grew faster on cold days, but were more likely to crack. Good iron candlesticks were rare, and at balls and parties potatoes were used, and wooden blocks. The evolution, I have heard, was first a "slut" or linen rag in fat, or a bowl of woodchuck's oil with a floating wick through a wooden button. Later came a square strip of fat pork with a thin sliver of wood thrust through to stiffen it and serve as a wick. Fire could still be made by friction of wood in an emergency. The best-raked fire would sometimes go out, and then fire must be borrowed from a neighbor. Those who wished to be independent obtained tinder-boxes with flint and iron, smudged tow and punk. Home-made matches, with brimstone and saltpetre, would catch readily, but friction matches were a great novelty. One of these friction matches, also home-made, of spruce lumber, by the boys, was "drawed" by their incredulous father, who, when he found it would really go, put it carefully in his pocket for future use.

The ideal hearth and fireplace of olden times (restored at Plymouth, and especially at Deerfield, Mass., by George Sheldon,) was indeed the centre about which the whole family system revolved. On the swinging crane, evolved from the earlier wooden lug-pole, hung from pot-hooks, chains and trammels, several species of iron pots and brass kettles, in front of a green back-log, so big and long that it was sometimes snaked in by a horse. Below, attached to the upright part of the andirons, was the turnspit-dog, revolved by hand, and sometimes, at a later date, by clockwork, for fancy roasts. There were roasters and dripping pans, and the three-legged spider, in which bread was baked, first on the bottom and then, tipped up to the coals, or else the top was done by a heavy red-hot 
iron cover. Here rye used to be roasted and mortared for coffee, which was later boiled in water and maple molasses. On the shelf or beam above the fire stood the foot stove, a horn of long and another of short paper lamplighters; a sausage stuffer; tin lanthorn; mortar; chafing dish; runlet; noggin; flatirons, perhaps of new fashion, hollowed for hot iron chunks; tinder box; tankard; and coffee pots; and high above all a bayoneted flint gun or two, with belt, bayonet sheath, brush and primer. Overbead on the pole hung always a hat or cap on the end, and perhaps a haunch of dried beef, with possibly a ham, a calf's rennet stretched with a springy willow stick inside; pumpkins cut into long ringlets; bundles of red peppers; braided seed corn and dried apples, the latter also perhaps half covering the roof and south side of the house. About the fireplace stood or hung the bed-warmer, the tongs, and long "slice," a hollow gourd or crooked-necked squash; candle holders with long tin reflectors; bellows; woolen holders; toasting irons; smoking tongs; pewter porringer; spoon moulds; trivet; skillet and piggin; a tin kitchen; a tin baker and steamer; a flip iron; the big dye tub always in the corner, and the high-backed settle in front. Near by stood the cupboard, displaying the best blue crockery, and the pewter, kept bright by scouring with horsetails (equisetum); sealed measures, and a few liquids, and perhaps near by a pumpkin Jack-o'-lantern, with an expression when it was lighted in the dark as hideous as that of the head of an Alaskan totem-post.

The grandma was both nurse and doctor, and the children had to gather for her each year a supply of herbs. Chief among these were pennyroyal, tansy, spearmint, peppermint, catnip, thoroughwort, motherwort, liverwort, mugwort, elecampane, opodeldoc, burdock, mayweed, dogweed, fireweed, ragweed, pokeweed, aconite, arnica, scratch-grass, valerian, lobelia, larkspur, mullein, mallow, plantain, foxglove or nightshade, osier, fennel, sorrel, comfrey, rue, saffron, flag, anise, snakeroot, yarrow, balmony, tag alder, witch-hazel, and bloodroot. Each of these, and many more, had specific medicinal properties, and hung in rows of dried bunches in the attic, and all grew in Ashfield. In Mr. Cockayne's Leechdom, Wortcunning and Starcraft, a remarkable collection of Anglo-Saxon medical prescriptions, I have identified the same symptoms for which the same herb was the specific, showing how this unwritten medical lore, as Mr. Mooney calls it in his interesting pamphlet, survives and persists unchanged.

The attic floor was covered a foot deep with corn on the ear, to be shelled winter evenings by scraping across the back of a knife driven into a board; the cobs being fed out to stock, or used for baking and smoking fires. Here, too, were tins and 
boxes, and barrels of rye and barley, and, later, oats, wheat and buckwheat. In the corner stood, or hung, perhaps, a hand-winnower, a tub of frozen cider apple sauce, an old hat and wig block, a few woodchucks' skins to be made into whiplashes, a coon skin for a cap, a hand-still for making cider brandy or twisted cider. So, too, the cellar, shed, hog-house, barn, sheep and horse barn, sugar-house and corn-house, were stored with objects of perennial interest to boys.

The "sense of progress," which a recent psychological writer calls a special, though lately evolved, sense, was by no means undeveloped. Men loved to tell of old times, when maple sap was caught in rough troughs made with an axe, and stored by being simply turned in their places; to show the marks on old maple trees, where their grandfathers tapped by chipping with a hatchet and driving in a bass-wood spout made at a blow with the same iron gouge that prepared for its insertion, and to describe how, later, the rough unpainted tubs with unbarked hoops, and, because smaller at the top, so hard to store and carry, and so liable to burst by the expansion of the ice on freezing, were superseded by the Shaker pails. The old days when sap was gathered by hand with a sap yoke, and stored in long troughs and boiled out of doors in a row of kettles on a pole or crotches, were talked over, with complacent pity, perhaps, while modern pans on a new arch and in a new sugarhouse were kept going all night during a big run which had filled every tun and hogshead, while the best trees were running over.

Hour-glasses, especially to spin by, and dials, were sometimes used, and there were many noon-marks at intervals over the farm. In many families, even where coal and kerosene stoves are used, along with wood, oven-wood is still cut for the old brick oven, which Christmas time, at least, if not once every week or two through the winter, is heated, and then swept out with a wet birch broom. First, the rye and Indian bread is made up in a bread trough and then put on the broad, meal-sprinkled peel, with hands dipped in water to avoid sticking, and very dexterously thrown in haycock and windrow shapes, perhaps on cabbage leaves, on to the bottom of the oven. When this was done it was still so hot that pies could be baked, and last of all, a bushel of apples was thrown in and the week's baking was over. Many could then tell of the time when, with pudding or mashed potatoes and milk for the meal, no table was set, but each took a bowl of milk and helped himself from the kettle on the stone; or again, the family gathered about the well-scoured table, with no individual plates or butter knives, or waiting on the table, but each took a slice of bread and helped himself from the meat dish, or dipped the 
brown bread into the pork fat with forks. Wooden, pewter, then earthen plates, was the order of evolution. So, in the dairy, milk used to be set in wooden trays, then in thick, brown earthen bowls, before the modern milk-pans came into vogue. The evolution of the skimmer from the clam shell, through a rough wooden skimmer; of churning, from a bowl and paddle on to the old dasher churn ; of straining milk, from the linen rag strainer, up; of bails, from the ear and peg fashion, on; the history of the artistic forms of butter balls, and the stamps used; the very gradual development of the scythe-snath, which no artist ever represents correctly, to the present highly physiological and very sharply discriminated forms, as well as of the hoe and pitchfork; why are not these and the growth of the corn-sheller, hen-coop, plough, mop, the story of the penstock, the broom, from a bush or bundle of twigs, up through the birch broom with fibres stripped both up and down; of window transparencies, from the hole and oiled paper, etc., as scientific anthropological themes, as the evolution of the fish-hook, arrow-head and spear? Why is not the old soap-making process, with the lye, strong enough to support an egg, dripping from the ash barrel on the circularly grooved board or stone, and the out-of-doors boiling and basket straining, etc.; why is not the old-fashioned semi-annual geesepicking day, with the big apron, great vase-shaped goose basket, and the baby's stocking drawn over the goose's head to keep it from biting; why is not cheese making, when the milk from three families was gathered in a big tub, coagulated with a calf's rennet, broken up into curds and whey by the fingers, scalded, chopped, salted, perhaps saged, hooped, turned, and pared of those delicious curds, and daily greased all summer; why is not the high festivity of road breaking in winter, when all the men and oxen in the neighborhood, often twenty yokes of oxen in one team, turned out after a long storm and blow to break out the roads which the town had not discontinued for the winter, to church, stores, doctor and school, when steers were broken in, sandwiched between the yokes of old cattle, where often up to their backs in a drift, with a sled to which ploughs were chained to each side and a dozen men and boys on it, they could only wait, frightened and with lolling tongue, to be shoveled out; why are not the antique ceremonies and sequelæ of butchering day, and the fun and games with pluck and lights and sausages, which city-bred boys were told, and said to believe, are caught like fish; the process of making pearl-ash and birch vinegar; cider-making; the manifold summer beers and other domestic drinks, etc., quite as worthy of investigation, of illustration in museums, as the no more rapidly vanishing customs of savage tribes? 
At the place and time of which I write many domestic industries were more or less specialized. Farmers' sons often went away to learn trades. Broom making, e.g., was the evening occupation of one member of the family I knew, and I saw the process of planting, breaking, tabling, hatchelling, for the seed was worth about the price of oats, bleaching with brimstone in a big down cellar, etc. Tying was the most interesting process. It included arranging the hurls, braiding down the stalks on the handle with wire, pressing in the great vise, and sewing with a six-inch needle, thimbled through by leather palms. I was allowed to sandpaper the handles, and once, in a time of stress, when a man was making forty plain Shaker brooms per day, even to put on the gold leaf. The local tanner allowed us to run among his vats, and see the hides salted, pickled, washed and limed, and, best of all, skived over the big beam. Last summer this tanner told me he believed his eighteen months in tanning an ox hide and the six weeks required by modern chemical methods, represented about the relative durability of the two leathers. His trade has lasted on, despite such competition, because his townsmen have something the same idea. Within boy-range, too, was a cooper's shop, a gunsmith, a family who made baskets, a small carding mill, turning shops where wooden spoons, bowls, sieve rims, pen handles, plain broom handles, etc., were made, a general tinker and solderer, besides carpenters, blacksmiths, shoe and harness makers. Some farmers specialized, more or less, in sheep; others in young cattle, or pigs and horses. Some were always lucky with corn, others with rye or wheat, buckwheat, potatoes, grass, etc., to which they had mainly settled after much experiment, or to which the traditions of the farm or family inclined them. 'Thus, in fine, there were many grades of progress and versatility. Many of these old home industries I can still practice and have added to them by "lessons" in Germany. All come handy in the laboratory. I know I could make soap, maple sugar, a pair of shoes, braid a palm leaf hat, spin, put in and weave a piece of frocking or a rag carpet, do crude carpentry, farm and dairy work, and I envy the pupils at Tuskegee who can do more of these things and better than $I$.

I have alluded to but few of the occupations of these people. Their commonest industries-planting, fertilizing, gathering each crop-have been revolutionized by machinery and artifcial fertilization within twenty-five years. These, and their religion and beliefs, and domestic social customs, methods of doing their small business, are all fast changing. The women are haggard and worn with their work, the men are sometimes shiftless, and children are very rare. The heart of these communities has left it, and only the shell remains. The quaint, 
eccentric characters that abound in these towns, types of which may be found faithfully depicted by Mary E. Wilkins or in Mary B. Claflin's "Brampton Sketches," or in a few of the sketches in "Profitable Tales," by Eugene Field, are for the most part types of degeneration well recognized by alienists and characterized by Morel. These are quite different from the no less rustic characters in De Gaspe's "Old Canadians, or the work of Du Pray's School." Life then and there, although perhaps a century or more later than that described in the books of Alice Morse Earle, did not differ much from it. Did the earlier generations work too hard in digging stumps and stones, and laying the hundreds of miles of heavy stone wall and clearing the timber? Were the conditions of life too severe? Is our race not adapted to the new conditions of climate, soil, water, and, as Dr. Jarvis said, is it still a problem whether the AngloSaxon race can thrive in its new American home, or is this but an incident, an eddy in the great onward current of progress? I have no answer, but I know nothing more sad in our American life than the decay of these townlets.

Nowhere has the great widdle class been so all-controlling, furnished so large a proportion of scientific and business leaders, been so respectable, so well combined industry with wealth, bred patriotism, conservatism and independence. The farm was a great laboratory, tending, perhaps, rather more to develop scientific than literary tastes, cultivating persistency, in which country boys excel, if at the expense of versatility. It is, says Prof. Brewer, the question with city parents what useful thing the children can do; while in the country, where they are in great demand on the farm they are, in a sense, members of the firm. Evenings are not dangerous to morality, but are turned to good account, while during the rowdy or adolescent age the boy tendency to revert to savagery can find harmless vent in hunting, trapping, and other ways less injurious to morals than the customs of city life.

Some such training the heroes of ' 76 had; the independent conditions of communities like this was just the reverse of that of the South at the outbreak of the Rebellion; such a people cannot be conquered, for war and blockade would only drive them back to more primitive conditions; and restore the old independence of foreign and even domestic markets. Again, should we ever have occasion to educate colonists, as England is now attempting, we could not do so better than by reviving conditions of life like these.

I close by mentioning an interesting new educational experiment, as a bright spot in this sombre present, which was somewhat feebly but happily tried in Ashfield, as a result of the recently awakened interest in its own antiquities. A prominent 
citizen, once a teacher, has studied from sources largely unprinted the history of the town, which connects it with the Revolution, and even the French and Indian wars, and on the lines of old map he has made of the original town surveys, gave an hour per week during part of a winter in teaching history, from a local standpoint in the little academy, with its score of pupils, and adding many of the antiquities such as this paper has referred to, with free use of the museum, and all with excellent results. A village pastor, who is an excellent botanist, took the class a few times each year on excursions, and the older girls have gathered and pressed for him in a school museum all the Ashfield plants and grasses, on the basis of which he taught a little botany gratuitously. The Doctor co-operated with them and talked on physiology and hygiene, and brought his miscroscope and other instruments. A student of an agricultural college has gathered all the Ashfield rocks and minerals and taught geology. He has gathered cabinets of the local animals, birds, eggs, butterfies, and insects, which a summer resident makes a basis of some instruction. A summer boarder was drafted in to teach drawing to all comers half a day per week. This experiment, in what I consider co-operative education, begins at home, with what is nearest and often despised. The local Faculty about the teacher give but little time, but their teaching is full of interest and stimulus. They strengthen the teacher whom they really guide, and bring home and school nearer together. This new curriculum is without expense, and altogether may prove a suggestive novelty. To-day old domestic industries of the age of the tinderbox and stone milk pan and niddy-noddy are taught by a specialist to history classes from the city schools in turn, by Miss H. B. Merrill, in a central museum of American antiquities in Milwaukee. 